\title{
A RADICAL CHURCH? A REAPPRAISAL OF ANABAPTIST ECCLESIOLOGY ${ }^{1}$
}

\author{
By John E. Colwell
}

\section{INTRODUCTION}

Though it could be claimed that there has been a revival of interest in the Anabaptists in recent years realistically one must admit that this has tended to be restricted to a renaissance amongst their spiritual descendants. Beyond the historical research pursued by Mennonites, Baptists and perhaps Brethren and Pentecostalists the Anabaptists remain liable to dismissal with a passing censorious reference to the polygamy and violence of Münster.

In optimum partem serious study of the Anabaptists may be inhibited not so much by prejudice as by the sheer difficulty and breadth of the subject. Who were the Anabaptists anyway? We are not referring to a single 'stream' or 'movement' but to a series of separate and largely independent groups some of which began to merge in the course of time; to an amalgam of differing strands in which the heterodox and the orthodox occasionally appear strangely blurred. That which survives of their own writings may be less than representative, is indicative of considerable difference of emphasis and sometimes exposes a lack of opportunity for detached and rigorous academic theological reflection on the part of the various writers. All of which is, of course, compounded by the danger inherent in all historical research (and into which this present paper may well fall) of only finding that which one's presuppositions determine one should seek.

That which unites the early Anabaptists (and several other reforming groups in the history of the church) is the

\footnotetext{
1 Bibliographic material additional to that cited in the footnotes may be found in the article 'Church' in The Mennonite Encyclopedia I (Scottdale, Herald Press 1955) 594; An Introduction to Mennonite History, ed. Cornelius J. Dyck (Scottdale, Herald Press 1981); The Writings of Pilgram Marpeck, trans. and ed. William Klassen and Walter Klaassen (Scottdale, Herald Press 1978); and The Complete Writings of Menno Simons, trans. Leonard Verduin, ed. John Christian Wenger (Scottdale, Herald Press 1956).
} 
agenda of issues they were probing, particularly in the sphere of ecclesiology. The intention of this paper is not just to review this unwritten agenda of issues but to attempt to define the distinctive ecclesiological perception or perceptions which led the major 'streams' of Anabaptists to address such issues in a particular manner.

\section{THE DISTINCTIVE ECCLESIOLOGICAL PERCEPTIONS OF ANABAPTISM}

The most obvious distinctive feature uniting the Anabaptist movement was their practice of baptism, yet it would be simplistic to fail to recognize that, in the majority of cases, the practice of believers' baptism was an expression rather than the root of a distinctive ecclesiology. The practice of believers' baptism was an expression of a commitment to discipleship and brotherhood within the church but these values were themselves derived from a conception of the nature of the church that distinguished the majority of Anabaptist writers from the magisterial reformers.

The magisterial reformers had recognized the mediaeval church to be a corrupt church but the Anabaptists went one stage further in declaring it to be a 'fallen church': to be allied to the state was to be allied to the world in its fallen state. Bernhard Rothmann, the Lutheran priest who first condemned infant baptism in Münster, identified this 'fall' of the church with the corruption of the pure gospel by the 'wordly wise, reasonable and educated ones of this world'.2 Predictably, for Michael Servetus as a representative of the anti-trinitarians the 'fall' of the church coincided with the affirmation of trinitarian doctrine at the Council of Nicaea $^{3}$ while Sebastian Franck, who expresses his 'spiritualized' view of the church in a letter written from Strassburg to John Campanus, held that the outward church of Christ, including all its gifts and sacraments . . . went up into heaven and lies concealed in the Spirit and in truth'; that is,

2 Bernhard Rothman, 'Restitution' (1534), quoted in Anabaptism in Outline: Selected Primary Sources [hereafter AO], ed. Walter Klaassen (Scottdale, Herald Press 1981) 330.

3

Cf. James Leo Garrett, The Nature of the Church according to the Radical Continental Reformation', The Mennonite Quarterly Review [hereafter MQR] 32 (1958) 111-27 (113). 
Franck and others like him held that there was no longer any valid expression of the true church on earth.4

A common link between Anabaptist writers therefore was that the church as it now existed needed more than reform, it needed 'restoration as a voluntary, disciplined, obedient society'.5 The statement of the Bern Colloquy is typical: 'the true church came to an end some time, and we have made a new beginning upon the rule from which others had departed.' 6 Similarly Conrad Grebel, the first leader of the Swiss Brethren in the Zürich area, encourages Thomas Müntzer by letter to: 'Go forward with the Word and establish a Christian church with the help of Christ and his rule....'7

This theme of the 'restoration' or better the 'restitution' of the true church ${ }^{8}$ is a common link between quite distinct and divergent Anabaptist groups who were perhaps more united in that which they rejected as marks of the 'fallen' church than in that which they affirmed as marks of the true church which was being restored. J. L. Garrett distinguishes four distinct ecclesiological types of 'true church' doctrine found in the radical Reformation: ${ }^{9}$

1. 'the restored, gathered congregation or brotherhood of baptized believers under discipline and separated from the world and from the state';

2 the Hutterian Brethren who shared the above concepts but with the addition of the 'apostolicity and necessity of community of goods' ${ }^{11}$ (this group together with the first group mentioned by Garrett could reasonably be considered to be the major 'streams' of Anabaptist life and thought);

3. the 'church-kingdom' which 'at Münster issued in a church-kingdomstate'; ${ }^{12}$

4 Sebastian Franck, 'A Letter to John Campanus' in Spiritual and Anabaptist Writers [hereafter SAW] ed. George H. Williams and Angel M. Mergal (Philadelphia, Westminster Press 1957) 147-60 (149).

5 Peter H. Davids, 'An Anabaptist View of the Church', EQ 56 (1984) 81-93 (83).

6 Bern Colloquy" (1538), quoted in AO 111.

7 Conrad Grebel and friends, Letters to Thomas Müntzer' in SAW 79f.

8 The word 'restitution' may be preferable to 'restoration'; cf. Frank J. Wray, The Anabaptist Doctrine of the Restitution of the Church', MQR 28 (1954) 18696.

9 Cf. Garrett, Nature of the Church' 115.

10 Ibid.

11 Nature of the Church' 117. 
4. the 'inward, invisible, universal, spiritual church, ungathered and without external sacraments or worship' 13 (Sebastian Franck's letter to John Campanus concerning the futility of attempting to restore the church can be taken as typical of the thought and attitudes of this final group). ${ }^{14}$

Of course not all individual personalities or groups can be fitted neatly into these general divisions (Michael Servetus, for example, held a similar view to the last mentioned group but could hardly be taken as typical), yet they are sufficient to illustrate the fact that while the various Anabaptist groups were responding to similar issues they were responding in quite different ways. What, therefore, were the reasons which caused them to respond in such different ways from one another and from the maigisterial reformers who themselves were certainly aware of the questions the Anabaptists were addressing?

To begin with one must state the obvious: the Anabaptist movement arose within the context of a church tradition in which everyone in Europe except Jews and heretics belonged to the church by virtue of baptism. In such a context the church and the state had come to be seen as differing aspects of the same entity. In his book The Reformers and their Stepchildren Leonard Verduin argues that Old Testament society and all preChristian society was 'sacral society' (i.e., a society 'held together by a religion to which all the members of that society are committed') and traces each aspect of the reaction to the Anabaptist movement to their rejection of such 'sacral society' ${ }^{15}$ That which distinguishes the major 'streams' of Anabaptist life and thought both from the magisterial reformers and from the 'church-kingdom' group (of which Münster is an example) is the rejection of this concept of a 'sacral society'. A reappraisal of Anabaptist ecclesiology must therefore begin by enquiring into those perceptions which caused most Anabaptist writers to reject the concept of a 'sacral society'.

It has already been recognized widely that one fundamental factor in the Anabaptists' rejection of the 'sacral society' concept was their understanding of the authority of

12 Nature of the Church' 118.

13 Nature of the Church' 120.

14 Franck, 'A Letter to John Campanus' in SAW $155 f$.

15 Leonard Verduin, The Reformers and their Stepchildren (Grand Rapids, Eerdmans 1964) 23. 
scripture and, in particular, of the relative authority of the Old and New Testaments. There were Anabaptist writers (Klaassen cites Hans Denck, Hans Hut and Ulrich Stadler) who rejected a simple identity of scripture (i.e., the outer word) and the Word of God (i.e., the voice of the Spirit; the inner word). ${ }^{16}$ Nonetheless amongst Anabaptists generally scripture was seen as the final authority for the Christian, providing models for teaching and church order; though the primary concern of the Anabaptists was not with intellectual questions of scripture's authority but with its effective authority in life - the humble obedience of the disciple to Jesus of whom scripture testified. But the perception which underlies their rejection of 'sacral society' was their affirmation that the Old Testament ought only to be interpreted in the light of the New. The 'Bern Colloquy' accepted the Old Testament as 'an announcement, witness, type or sign of Christ' and acknowledged its validity 'insofar as it illuminates and reveals Christ', but it asserted that 'the punishment of the body to death' was neither established nor commanded by Christ', the only form of discipline sactioned by the New Testament was 'the Christian ban' (i.e., exclusion from the congregation). ${ }^{17}$ Dietrich Philips speaks of all things being 'changed in Christ . . . from the letter to the Spirit'.18 Similarly William Estep comments on the contribution of Pilgram Marpeck:

Marpeck's most creative contribution to Anabaptist thought was his view of the Scriptures. While holding the Scriptures to be the Word of God, he made a distinction between the purpose of the Old Testament and that of the New. . . The New Testament was centered in Jesus Christ and alone was authoritative for the Brethren... Failure to distinguish between the Old and New Testaments leads to the most dire consequences. Marpeck attributed the peasants' revolt, Zwingli's death, and the excesses of the Münsterites to this cause. Making the Old Testament normative for the Christian life is to follow the Scriptures only in part. .. If Marpeck had made no other contribution to Anabaptist theology than this one insight, would it not be sufficient to make him worthy of recognition? ${ }^{19}$

Without doubt this perception of the distinction between the twc Testaments was a fundamental factor in the rejection of the concept of a 'sacral society' just as surely as a perception of theis

17 'Bern Colloquy' (1538), quoted in $A O 151$

18 Dietrich Philips, 'Spiritual Restitution' (1560), quoted in AO 158.

19 William R. Estep, The Anabaptist Story (Grand Rapids, Eerdmans 1975) 866 . 
equality was a root cause of the tragedy at Münster. ${ }^{20}$ Klaassen observes that both the rejection of participation in government and nonresistance are aspects of the refusal to use the sword which arose from the Anabaptists' distinction between the two covenants.

However, there may be another factor which determined the differing ecclesiologies of the early Anabaptists, albeit a perception which is related to their understanding of scripture and which is more implicit in their writings than explicit. Ecclesiology is at least in part determined by eschatology and it is one purpose of this paper to suggest that it was a difference of implicit eschatology that determined the ecclesiological perception of the major 'streams' of Anabaptists and distinguished them not only from the magisterial reformers but also from the two other groups which Garrett identifies.

Klaassen notes that, while each Anabaptist stream was generally characterized by the belief that they were living in the last days they nonetheless 'disagreed in emphasis' and in regard to their own 'attitude toward and participation in the expected events'. ${ }^{21}$ It is this difference of expectation concerning the degree, manner and imminence of participation in eschatological events that underlies the rejection of the concept of a 'sacral society' amongst the major 'streams' of Anabaptism.

Although Thomas Müntzer was generally dismissed as a 'fierce fanatic, possessed of a demoniac spirit which finally hurled him into the leadership of the rebellious peasants of Middle Germany, 2 the implicit eschatology which determines his ecclesiology is essentially identical to that of the magisterial reformers and the mediaeval church since Augustine. To describe the view as a-millenialist or post-millenialist may be anachronistic but nonetheless Müntzer's ecclesiology sprang from the belief that the contemporary church now participated in the victorious reign of Christ. ${ }^{23}$ It is this implicit eschatology

20 Garrett, Nature of the Church' 119.

21 AO 316

22 George H. Williams, The Radical Reformation (Philadelphia, Westminster Press 1962, 44f.

23 For Garrett to comment that 'most pronounced millenarian movements have been non-violent' ('Nature of the Church' 126). is to fail to recognize the essential distinction between pre-millenialism on the one hand and post-millenialism and a-millenialism on the other and that the latter, rather than the former, is that which characterized Münster. 
that underlies the concept of a 'sacral society' and issues in the expectation of a theocracy on the model of Old Testament Israel. Thus the imagery of David's kingdom figures prominently in Müntzer's 'Sermon before the Princes' ${ }^{24}$ and in the writings of other Anabaptists in the 'church-kingdom' stream who shared his implicit eschatology and therefore also shared his ecclesiological expectations. In such a theocracy it was the role of the 'godly prince' to wield the sword on behalf of the church in order to 'wipe out the godless'. ${ }^{25}$ In an article concerning Müntzer's relationship to the other major 'streams' of Anabaptist life Robert Friedmann comments:

his Allstedt League was anything but an Anabaptist brotherhood; it was rather a conspiratorial secret society to promote the imminently expected kingdom of God by means of wiping out, if need be by the sword, all [Catholic] superstition - a chapel was burned down - and all ungodliness. Of a restitution of the primitive church in the Anabaptist sense there is no trace whatever, since Müntzer completely lacked the idea or vision of discipleship and obedience to the Word of God. 26

This same implicit eschatology is at the root of the tragic events at Münster. Again we find the imagery of the 'kingdom and throne of David' employed by Rothmann:27

He will strengthen the hand of David and will instruct his fingers for the battle. God will make for his people bronze claws and iron horns. They will make plowshares and hoes into swords and spears. They shall choose a captain, fly the flag, and blow the trumpet. They will incite an obstinate and merciless people against Babylon. In everything they will repay Babylon with her own coin, yes, in double measure. ${ }^{28}$

Rothmann regarded Münster as the 'centre of the coming kingdom', a kingdom the Münsterites believed 'had already begun with the reign of Jan van Leyden'.29 Old Testament imagery was employed because implicit eschatological expectation enabled it to be employed. The theocracy at Münster

24 Thomas Müntzer, 'Sermon before the Princes' in SAW68f.

25 Müntzer, 'Sermon before the Princes' in SAW 68f.

26 Robert Friedmann, Thomas Müntzer's Relation to Anabaptism', MQR 31 (1957) 85; quoted by Garrett, Nature of the Church' 119.

2 Rothmann, 'Restitution' (1534), quoted in AO 253.

28 Rothmann, 'Concerning Vengeance' (1534), quoted in AO 335.

29

$\mathrm{AO} 317$. 
may have differed from the theocracy at Geneva in its degree of violence but it differed not at all in fundamental ecclesiological principle. Consequently Garrett distinguishes the Münsterite theocracy from the 'gathered church' concept of the major 'streams' of Anabaptism since the former was itself:

a state church captured by rebaptizing, chiliastic Spiritualists and never reconstituted on the basis of professed believers only. Likewise, Münsterite baptism was the forced baptism of adults, but not necessarily of those professing faith or evidencing regeneration. Furthermore, the Münsterite theocracy differed from both general and Hutterite Anabaptism in its use of the sword and denial of liberty of conscience and in its lack of discipline after the New Testament pattern. ${ }^{30}$

In many ways the fourth ecclesiological group mentioned by Garrett represents the opposite edge of the spectrum by its total rejection of every form of imminentism; here any form of representation of the kingly rule of Christ in his church lies wholly in the future. Sebastian Franck's view of a clear demarcation between the church of the first apostles and the contemporary church and of the futility of any attempt to restore the contemporary church is an outcome of a depressing expectation for the imminent future not entirely dissimilar to that of modern dispensationalism. The best one can presently hope for is to keep a low profile. ${ }^{31}$ Reading Obbe Philips' account of the events at Münster and his own sense of utter disillusionment one can understand the attractions of this fourth 'stream'. ${ }^{32}$

\section{THE IMPLICIT ESCHATOLOGY OF ANABAPTIST ECCLESIOLOGY}

However, neither Obbe's brother Dietrich, nor Menno Simons (both of whom were 'ordained' elders by Obbe) followed him in his disillusionment and reaction. The major 'streams' of Anabaptism follow a distinct ecclesiological path to either the 'church-kingdom' group or the 'spiritualist' group inasmuch as they share a distinct eschatological expectation. This

30 Garrett, Nature of the Church' 119.

31 Franck, 'A Letter to John Campanus' in SAW $155 f$.

32 Obbe Philips, 'A Confession: Recollections of the years 1533-1536' in SAW 206-25. 
eschatological expectation is implicit rather than explicit; there is little to find in their writings by way of clearly defined eschatology. While therefore it is probably unhelpful to define this expectation as a form of non-dispensationalist premillenialism it is nonetheless distinguishable from the 'spiritualist' group in its affirmation of an expectation for the restitution of the contemporary church and distinguishable from the 'church-kingdom' group, the magisterial reformers and the mediaeval church in its recognition of the limitations of this expectation in the present.

The limitations of this expectation are particularly apparent in the 'non-coercive' and 'non-resistant' elements of these 'streams' of Anabaptism. Although Hans Hut had been greatly affected by the eschatological expectations of Thomas Müntzer, Hans Denck had a moderating influence upon him, particularly in terms of his eschatology, to the degree that Klaassen refers to him as 'interim-nonresistant': the sword 'had been taken away until God would tell them to take it out again ... until then they were to be nonresistant'. ${ }^{33}$ More typically, Dietrich Philips can refer to the church in the present in terms of the 'New Jerusalem' of Revelation 21 without embracing the implications of a coercive theocracy typical of a 'sacral society'. ${ }^{34}$ A wholly different application of the imagery of the throne of David to that employed by Müntzer is found in the writings of Peter Riedeman. Quoting the text The sceptre shall not depart from Judah until the hero, Christ, shall come' Riedeman argues that since Christ has now come and now 'sits upon the throne of his father, David', a 'new regime' has begun which cannot be 'supported by the temporal sword'. The power of this 'temporal sword' has been taken from the Jews and passed to the 'heathen' signifying that 'from henceforth the people of God ought no longer to use the temporal sword and rule therewith; but ought to be the ruled and led by the one Spirit of Christ alone'. Hence 'no Christian is a ruler and no ruler is a Christian ... the power of the sword has passed to the heathen, that they may therewith punish their evildoers. But that is no concern of ours' ${ }^{\prime 35}$

Now since Christ, the Prince of Peace, has prepared and won for himself a

AO 266.

Dietrich Philips, 'The Church of God' in SAW 255ff.

Peter Riedeman, 'Account' (1542), quoted in $A O 260 f$. 
kingdom, that is a church, through his own blood; in this same kingdom all worldly warfare has an end, as was promised aforetime, 'Out of Zion shall go forth the law, and the word of the Lord from Jerusalem, and shall judge among the heathen and shall draw many peoples, so that they shall beat their swords into ploughshares and their lances or spears into pruning hooks, sickles and scythes, for from thenceforth nation shall not lift up sword against nation, nor shall they learn war any more. 36

Thus Riedeman's eschatological expectation for the contemporary church is the complete opposite of that expressed by Thomas Müntzer whose view was 'worked out' at Münster; although Riedeman employs precisely the same metaphors he does so in a completely opposite way. Among the major 'streams' of Anabaptism the expectation for the restored church as a gathered brotherhood of disciples is that it should be a true expression now of the presence of Christ and his kingdom but the fufilment of that kingdom in judgement and glory lies in the future. Thus Peter Davids writes:

The Christ who is followed, however, is the suffering Christ, not the glorified Christ. It is true that the time of glorification is coming, either after death or after the return of Christ, but now one walks in the footsteps of the poor, meek Christ of the gospels, who suffered and yet blessed, and who died a martyr's death. This is what is meant by 'the baptism of blood' (as opposed to those of water and of the Spirit) or 'the bitter Christ'.37

To be a 'joint heir' with Christ according to Hans Hut implies a commitment to 'suffer with him', to 'follow the footsteps and ways of Christ', 'to carry the cross of Christ'.38 The Christian has surrendered to 'the holy cross' of Christ' with 'holy patience'. ${ }^{39}$ Verduin comments that to understand 'crossbearing in terms of sickness rather than in terms of persecution is always a mark of a 'sacral society' and is indicative of what the Anabaptists saw as the 'fall' of the church. 40

Menno Simons speaks of true Christians as those 'who do not know vengeance' but pray 'Father forgive them; for they do not know what they $\mathrm{do}^{\prime 41}$ as those who are 'the children of

36 Riedman, 'Account' (1542), quoted in $A O 277$.

37 Davids, 'Anabaptist View' 85.

$38 \mathrm{H}$. Hut, 'A Christian Instruction', quoted in AO 89.

39 Pilgrim Marpeck, 'Concerning the Love of God in Christ, quoted in $A O 96 f$.

40 Verduin, Stepchildren 257.

41

Menno Simons, Reply to False Accusations' (1552), quoted in AO 281. 
peace who have beaten their swords into plowshares and their spears into pruning hooks, and know war no more. They give to Caesar the things that are Caesar's and to God the things that are God's', ${ }^{42}$ as those whose weapons 'are not weapons with which cities and countries may be destroyed, walls and gates broken down, and human blood shed in torrents like water' but 'weapons with which the spiritual kingdom of the devil is destroyed and the wicked principle in man's soul is broken down, flinty hearts broken, hearts that have never been sprinkled with the heavenly dew of the Holy Word'.43

Though James Stayer has shown that the conviction concerning the total rejection of the sword came gradually among the Swiss brethren, the South Germans and the Dutch Anabaptists, the first 'witness' to its total rejection is Conrad Grebel in his letter to Müntzer:44

the gospel and its adherents are not to be protected by the sword, nor are they thus to protect themselves, which, as we learn from our brother, is thy opinion and practice. True Christian believers are sheep among wolves, sheep for the slaughter; they must be baptized in anguish and affliction, tribulation, persecution, suffering, and death; they must be tried with fire, and must reach the fatherland of eternal rest, not by killing their bodily, but by mortifying their spiritual enemies. Neither do they use worldly sword or war, since all killing has ceased with them - unless, indeed we would still be of the old law. And even there [in the Old Testament], so far as we recall, war was a misfortune after they had once conquered the Promised Land. No more of this. ${ }^{45}$

Similarly, Michael Sattler, on trial for his life, is recorded as saying: 'if the Turks should come, we ought not to resist them. For it is written [Mt. 5:21]: Thou shalt not kill. We must not defend ourselves against the Turks and others of our persecutors, but are to beseech God with earnest prayer to repel and resist them.' 46

The distinction between the eschatological expectation of the 'church-kingdom' stream and the implicit eschatology of the major 'streams' of Anabaptism can be illustrated by the use made of the parable of the wheat and the tares. Müntzer used

42 Menno Simons, The New Birth' (c. 1537), quoted in AO 109.

43 Menno Simons, 'Foundation' (1539), quoted in AO 276.

44 AO265

45 Conrad Grebel and friends, 'Letters to Thomas Müntzer' in SAW 80.

46 Michael Sattler, 'Trial' (1527), quoted in AO 270. 
the parable as a justification for magisterial persecution, that is, he believed that harvest time had already come and therefore the tares should be violently separated from the wheat. Menno Simons and Pilgram Marpeck both refer to the parable but are not influenced by Müntzer's imminentist eschatology. The field in the parable is the world and not the church: at the future harvest the tares of the world will be separated from the church; until such time the church must continue a stance of noncoercion and non-resistance in relation to the world and its tares. Nonetheless, since the field of the parable is the world and not the church the prohibition concerning anticipating the harvest applies to the world and not to the church, that is, the parable cannot validly be employed as an argument against church discipline. Christians must not prematurely 'usurp the judgment and kingdom of Christ', he alone is the 'Ruler of the conscience .47 While true Christians can expect to be persecuted they are to persecute 'no one on account of his faith'; the sheep does not devour the wolf, but the wolf the sheep':48

From this it is evident that no congregation of the Lord may exercise dominion over the consciences of men with the outward sword, nor seek by violence, to force unbelievers to believe, nor to kill the false prophets with sword and fire; but that she must with the Lord's Word judge and expel those in the congregation who are found wicked; and what is done over and above this is not Christian, nor evangelical, nor apostolic. ${ }^{49}$

Marpeck's rejection of the place of physical coercion in the church is worthy of a lengthy quote:

I admit worldly, carnal, and earthly rulers as servants of God in earthly matters, but not in the kingdom of Christ. According to the words of Paul, to them rightfully belongs all carnal honour, fear, obedience, tax, toll, and tribute. However, when such persons who hold authority become Christians (which I heartily wish and pray for) they may not use the aforementioned carnal force, sovereignty or ruling in the kingdom of Christ. It cannot be upheld by any Scripture. To allow the external authority to rule in the kingdom of Christ brings blasphemy of the Holy Spirit, who alone is Lord and Ruler without any human assistance. And if false teachers desire to lead astray, the true sheep do not listen to the voice of strangers; they are soon known by them. Where the governmental authority is used, as it was in the Old Testament, to root out the false prophets,

\footnotetext{
47 Simons, 'Foundation' (1539), quoted in AO 257,

48 Dietrich Philips, The Church of God' in SAW 252.

49

Philips, 'The Church of God' in SAW 253.
} 
Christ's Word and Spirit are weakened, and are turned into a servile spirit designed to uphold insufficient and weak laws. For the Word of God is the sharp, two-edged sword, separating and chastising false and true, good and evil. 50

This 'non-coercive' and 'non-resistant' stance was totally rejected by the major magisterial reformers. Leonard Verduin quotes Bullinger's comments on the Anabaptists' claim for freedom from coercion (and similarly quotes Bucer) to demonstrate that it was not the case that the reformers did not understand what was being claimed; Bullinger knew the claims and rejected them as did Bucer. ${ }^{51}$

This implicit eschatology issuing in a rejection of the concept of a 'sacral society' as envisaged in the Old Testament led the major 'streams' of Anabaptism to presuppose a radical discontinuity between the kingdom of God (of which the church was a present manifestation and realization) and the kingdom of this world represented by the present system. The state belongs to the old order while the church belongs to the new order..$^{52}$ According to Menno Simons:

The Scriptures teach that there are two opposing princes and two opposing kingdoms: the one is the Prince of peace; the other the prince of strife. Each of these princes has his particular kingdom and as the prince is so is also the kingdom. 53

Robert Friedmann considers this 'two world concept' to be the essence of Anabaptism whereby they 'felt themselves engaged in an inevitable conflict with the present world order':

These two views, the kingdom present in every reborn Christian (or present where two or three are assembled in the Master's name), and the kingdom as the new order to be expected at any moment and for which proper preparation is needed, are intermixed in Anabaptist thought just as they are in the original source of that teaching, the Gospels. ${ }^{54}$

50 Pilgram Marpeck, 'Confession' (1532), quoted in AO251f.

51 Verduin, Stepchildren $75 \mathrm{ff}$.

52 Davids, 'Anabaptist View' 82, 85.

53 Simons, 'Reply to False Accusations' (1552), quoted in AO 280.

54 Robert Friedmann, 'The Doctrine of the Two Worlds' in The Recovery of the Anabaptist Vision, ed. G. F. Hershberger (Scottdale, Herald Press 1957) 110-11, quoted in Estep, Anabaptist Story 179. 
Klaassen is therefore surely wrong to suggest that the Anabaptist version of the two kingdoms doctrine was virtually identical with that of Martin Luther. While Anabaptists certainly agreed that government was instituted by God their concept of 'two kingdoms' was not so much a distinction between a rule of law and a rule of grace as the distinction between the kingdom of God and the kingdom of Satan (with coercion being an aspect of the latter). For Luther the Christian ought to participate in government and to coerce the neighbour out of love for the neighbour. For the Anabaptists love for neighbour prohibited the possibility of coercion: No Christian, who wishes to boast in his Lord may use power to coerce and rule' ${ }^{55}$ Nonetheless there was the recognition that government had the right to wield the sword (in capital punishment). Only the Hutterites refused to pay taxes for either war or for payment of an executioner. ${ }^{56}$ Michael Sattler (who formerly was a Benedictine prior, was the leading figure in the formulation of the Schleitheim Confession and was brutally executed by fire at Rottenburg) speaks of the sword as 'an ordering of God outside the perfection of Christ' but nonetheless acknowledges that 'secular rulers are established to wield the same'.57

Generally speaking the major streams of Anabaptism assumed a distinction between submission to secular authority and 'blind obedience' (or allegiance) to secular authority. ${ }^{58}$ Peter Riedeman, a leader of the Hutterites and a major representative of their thought, comments: 'one should be obedient and subject to rulers as ordained by God for the purpose of protection, in so far as they do not attack the conscience or command what is against God' ${ }^{59}$ Similarly Jacob Hutter speaks of the necessity to 'obey God more than man'.60 Balthasar Hubmaier is an exception among Anabaptist leaders in not just accepting that a Christian could hold magisterial office as a 'just and Christian judge' but seeing this almost as a Christian duty, though he qualifies this with the reminder that

\footnotetext{
55 Hans Denck, 'Concerning True Love' (1527), quoted in $A O 270$.

56 AO $244 f$.

57 Michael Sattler, 'Schleitheim Confession' (1527), quoted in AO 268.

58 Davids, 'Anabaptist View' 87.

59 Riedeman, Confession of Faith 104; quoted by Davids, 'Anabaptist View' 86.

60 Jacob Hutter, Plots and Excuses', quoted in $A O 252 \mathrm{f}$.
} 
he must 'render an account on the last day' that he has employed the sword as 'nothing else than the beneficent rod and scourge of God, with which he is commanded to chastise the evil'. ${ }^{61}$ The more usual response to such questions by Anabaptist writers was to recall that Christ refused to arbitrate in a secular dispute concerning an inheritance and refused to condemn an adulteress: the servant is not greater than his Lord. ${ }^{62}$ The Anabaptists' perception of the eschatological distinction between the kingdom of God and the kingdom of this world meant that it would be pragmatically impossible for the Christian's conscience to 'allow him to be a magistrate': ${ }^{3}$

The wisdom of the office of the worldly rulers is designed to work through the external sword in vindictiveness, mercilessness, hate of sin, physical vengeance, killing of evildoers, worldly natural governments, judgments, and similar things. It is therefore without foundation to say that no one can exercise worldly government better than a Christian. That would imply that he needed the wisdom of Christ for it or that Christ's wisdom is the wisdom of his office. Christ's wisdom is merciful and will not serve him in his office because he is not merciful in his office but rather an avenger.$^{64}$

\section{THE ECCLESIOLOGICAL 'TMMINENTISM' OF ANABAPTISM}

The concepts of the 'gathered' church, of believers' baptism and of the place and manner of church discipline can all be seen as implications of an ecclesiology determined by this distinctive eschatology. Since the kingdom of this world has not yet become the kingdom of our Lord (Rev. 11:15) the concept of a 'sacral society' must be rejected and with it the assumption that the members of such a society are necessarily members of the church. The church rather must be seen as a brotherhood 'gathered' without coercion of those who are truly disciples of Jesus Christ, a 'visible' church (as the term ecclesia suggests). ${ }^{65}$ The Anabaptists did not therefore see themselves as schismatics; they had not left the true church, they had simply joined it:

61 Balthasar Hubmaier, 'Concerning the Sword' (1527), quoted in AO 249.

62 Cf. 'Justification of the Brothers' (1539), quoted in AO 254f.; also Sattler, 'Schleitheim Confession' (1527), quoted in $A O$ ' $268 \mathrm{ff}$.

63 Pilgrim Marpeck, 'Defence', quoted in AO 263.

64 Pilgrim Marpeck, 'Explanation of the Testaments', quoted in AO $262 f$.

65 Dietrich Philips, quoted in AO 115. 
I have not left the true Christian Church; I have but joined her and let myself be incorporated into her by true Christian baptism. I have no doubt that I am in the true community and fellowship of the saints ... Thus I have not left the true Christian Church, but the so-called 'Christian' congregation of sinners and the unjust, prostitutes, adulterers, gamblers, slanderers of God, gluttons, winebibbers, liars, covetous men and idolaters who do not cease to rouse God to wrath. 66

Given such an ideal of the church it is hardly surprising that the Anabaptists were accused of believing themselves to be not only a gathered church but a pure church, a sinless church, even though they denied this charge vehemently ${ }^{67}$. The purity of the church was an aim to be fulfilled eschatologically, not a present actuality. Thus Hans Denck, speaking of baptism, states: 'This does not mean that all who are baptized believe in God, but that they are all regarded as believers in so far as it is possible to recognize this.' ${ }^{68}$ That the Anabaptists believed in a 'gathered' church as an actuality rather than a 'pure' church as an actuality is determined by the importance with which they viewed the ban. The ban is only necessary given the expectation that the church is not yet pure. Rather, the actual purity of the church is the aim of the ban.

The practice of believers' baptism amongst the major streams of Anabaptism did not arise merely from the scriptural recognition of the wrongness of infant baptism and the consequent rightness of adult baptism (as at Münster) but was seen as the scriptural and appropriate means of entry into this non-coercive 'gathered' brotherhood (in distinction to Münster). Baptism was therefore: 'the external act by which Anabaptists expressed their rejection of the sacramental church of Rome and the territorial churches of Protestantism'. ${ }^{69}$ However, believers' baptism was not merely the means of entry to the 'gathered' church, it was also seen as indicative of repentance and identification with the death, burial and resurrection of Christ; ${ }^{70}$

66 Nicholas Felbinger (a Hutterite) quoted by Robert Friedmann, 'Claus Felbinger's Confession of $1560^{\circ}$, MQR 29 (1955) 155; cited by Garrett, Nature of the Church' 117.
67 Verduin, Stepchildren 102f.; Estep, Anabaptist Story 161.
68 Hans Denck, 'Recantation' (1527), quoted in $A O 168 f$.
${ }^{6} \mathrm{AO} 162$.
7 Cf. Sattler, 'Schleitheim Confession' (1527), quoted in AO 168. 
as indicative of a determined abandonment of the old life of sin and an acceptance of 'the process of discipline' and 'of mutual aid both spiritually and materially. ${ }^{71}$

All this implies a higher expectation for the Christian life than could have been possible within the 'sacral society' which Anabaptism rejected. Hans Denck's expectation is that 'Whoever has recognized the truth in Christ Jesus and obeys it from the heart is free from sin, although he is never free from temptation.' 72 By a work of the Holy Spirit the true Christian had been 'created anew in the image and likeness of God through Jesus Christ. ${ }^{73}$ That which Leonard Verduin refers to as 'conductual-averagism' is an inevitable consequence of a commitment to the concept of a 'sacral society'. ${ }^{74}$ In such a context the magisterial reformers, like the church of Rome, continued to be more concerned for (what they considered to be) purity of doctrine than purity of life. In contrast to the claim of Jesus that his true followers would be recognized by their 'fruits' they dismissed the manifest godliness of the early Anabaptists as a 'bait' of Satan designed to lure the saints into error: had not 'conductual-rigorism' been a common factor in all major heresies?

George Williams, commenting on Schwenckfeld's rejection of Luther's definition of the Christian as simul justus et peccator, suggests that it had been the palpable failure of Lutheranism to change the moral life of its proponents, especially among the simple parishioners. ${ }^{\prime 7}$ In contrast the context of the 'gathered' church of committed disciples enabled the Anabaptists to reject Luther's separation of works and faith. The obedience of discipleship demanded by the New Testament must necessarily be a possibility for the true Christian: ${ }^{76}$ Faith alone and by itself is not sufficient for salvation ... faith by itself alone is not worthy to be called faith, for there can be no true faith without the works of love. 77

71 AO 162; cf. Estep, Anabaptist Story 158.

72 Denck, 'Recantation' (1527), quoted in AO46.

73 Dietrich Philips, 'Regeneration and the New Creature' (1556), quoted in $A O$ 63 ff.

74 Verduin, Stepchildren.

75 George H. Williams, The Radical Reformation (Philadelphia, Westminster Press 1962) 109f.

$76 \mathrm{AO} 42$. 
In this sense the major 'streams' of Anabaptism maintained a form of imminentism wholly distinct from that of the 'church-kingdom' group. Faith is not an 'empty illusion', it is 'a real divine power, which renews man and makes him like God in nature, makes him living in his righteousness, and ardent in love, and in keeping his commandments', the Holy Spirit makes all believers 'free from the law or power of sin, and plants them into Christ, makes them of his mind, yea, of his character and nature, so that they become one plant and one organism together with him. ${ }^{\prime 78}$ Klaassen also records that, especially among the Dutch Anabaptists, there was the conviction 'that once God works in human life by his Spirit an ontological change takes place. ${ }^{79}$

Though there were certainly docetic elements in the Christology of some Anabaptist writers, expressing itself in the concept of Christ's 'heavenly flesh', the major streams of Anabaptism were united in the belief that the believer had been transformed into the image of Christ. The consequent expectation for the Christian life is the particular form of imminentism compatible with their implicit eschatology (this doctrine of Christ's 'heavenly flesh' was, after all, only another device for achieving doctrinally what was achieved elsewhere by the doctrine of Mary's sinlessness and immaculate conception, nor is it wholly dissimilar to that form of implicit docetism by which 'orthodoxy' condemned Edward Irving in the ninteenth century). 80

This expectation for Christian discipleship, together with the rejection of physical coercion, was the context of the Anabaptists' stress upon church discipline. The motive for discipline, and ultimately the 'ban' was their concern for the integrity of the church. Dietrich Philips lists three principle reasons for the use of the ban: first, that 'the church may not become a partaker of the sin of outsiders'; secondly, 'that the person who has sinned may be ashamed and his flesh be thus punished, and his spirit saved'; thirdly, 'that the church of God be not blasphemed on account of the evils in it. ${ }^{81}$

77 Balthasar Hubmaier, Justification' (1526), quoted in AO $43 \mathrm{f}$.

78 Riedeman, 'Account' (1542), quoted in AO $63 \mathrm{ff}$.

79 AO 42.

80 Cf. Verduin, Stepchildren 254. 
Anabaptist church discipline must be understood in the context of the manner of church discipline current in both Roman Catholic and Protestant churches, the force of which many of the Anabaptist writers were to experience. The harshness of the ban must be seen in the context of the harshness of the fire and the sword. For a 'sacral community' there was no longer a world into which an offender could be excommunicated. Rather the 'secular arm' effected the logic of excommunication (to no longer be part of the church was to no longer be part of sacral society). The Anabaptists differed in maintaining that there was a 'world', a 'kingdom of Satan,' into which the offender could be excommunicated and that the 'sword' of government had no place in the church nor in its internal affairs. ${ }^{82}$ Having commented that in the Old Testament context of a 'sacral society' there was a place for physical coercion Menno Simons continues:

But now the Holy Spirit does not teach us to destroy the wicked, as did Israel, but that we should sorrowfully expel them from the church, and that in the name of the Lord, by the power of Christ and the Holy Spirit, since a little leaven leavens the whole lump. 83

The 'ban' was applied with differing degrees of strictness in different Anabaptist groups. Pilgram Marpeck, who perhaps was a little more perceptive of human nature and its failings, censured the Swiss brethren for their Tharsh, legalistic way of exercising discipline in their congregations. ${ }^{84}$ These differences of strictness are best expressed in a letter addressed to Menno Simons:

We must make determined efforts for the purity and preservation of the church, and that the fallen brother and sister is prepared for repentance. This must be done with moderation according to the witness of Scripture, with aid, mercy, and helpfulness to them when necessary... We also fervently desire that the brothers in the Netherlands do not counsel husband and wife to separate in the ban. Damage and vice will follow from it rather than God's praise and the welfare of souls. The commandment regarding marriage outweighs the one regarding shunning. ${ }^{85}$

81 Dietrich Philips, 'Concerning the Ban' (1558), quoted in AO $225 f$.

82 Cf. AO 211ff.

83 Menno Simons, 'Account of Excommunication' (1550), quoted in AO229.

84 Pilgrim Marpeck, 'Judgement and Decision' (1542), quoted in $A O 223 f f$. 
Moreover, for all the harshness of the ban amongst some Anabaptist groups it must be remembered that the motive for the offender was always 'that he may be ashamed ... that perchance he may be moved thereby and return the more quickly to God:' ${ }^{86}$ 'we do not want to expel any, but rather to receive; not to amputate, but rather to heal; not to discard, but rather to win back; not to grieve, but rather to comfort; not to condemn, but rather to save. ${ }^{\prime 87}$

The outcome of the Anabaptists' expectation of Christian discipleship was a belief in the integrity of the church as truly the 'body of Christ' and here again their particular form of imminentism can be seen. With reference to the authority to bind and loose sins Balthasar Hubmaier comments that the universal church now exercises that power 'Christ had when formerly a man bodily present here';88 'Anabaptism transferred what in Catholicism were sacerdotal powers, to the whole Christian congregation.' 89

Klaassen comments that 'the Anabaptists talked more about the Spirit than others did'; they 'believed that they were living in the age of the Spirit the time when every child of God would have the Spirit'; that they 'spoke, almost naively, about being led by the Spirit, and being given divine illumination. ${ }^{\prime 90}$ In this sense the Anabaptists believed not only in the 'priesthood' of all believers but also (in Wheeler Robinson's phrase) they believed in the 'prophethood' of all believers. ${ }^{91}$ Believing in the unity of the one Spirit they expected complete unity and harmony in every aspect of the life of the church. Peter Davids comments: The Schleitheim Confession repeatedly uses the phrase "we are united" as a preface to each article. The Confession is the will of God because not a majority, but total unity shows the presence of the Spirit.' 92

\footnotetext{
85 Letter of Zylis and Lemke to Menno Simons' (1557), quoted in AO 231.

86 Riedeman, 'Account' (1542), quoted in $\mathrm{AO} 220 \mathrm{Of}$.

87 Menno Simons, 'Admonition on Church Discipline' (1541), quoted in AO 219.

88 Balthasar Hubmaier, 'Basis and Cause' (1526-7), quoted in AO 213.

89 AO 102 .

$90 \mathrm{AO} 72$.

91 Garrett, Nature of the Church' 126.

92 Davids, 'Anabaptist View' 92.
} 
Similarly Anabaptists 'switched' the terms of discussion of the presence of Christ in the Lord's Supper to that of his presence in the 'body' of believers; not a sacramental presence but a presence expressing itself in ethical and moral terms and in the exercising of the rule of Christ. In such a context the supper became an expression and a celebration of the unity of the body, the visible community of believers, as 'the presence of God in the world'; the bread and wine became signs of this unity as well as signs of sacrifice. Participation in the supper was indicative of a willingness to participate in one another's spiritual and material needs: ${ }^{93}$

It is a public token and testimony of love, in which one brother pledges himself to another before the church. Just as they are now breaking bread and eating with one another, and sharing the cup, so each will offer up body and blood for the other, relying on the power of our Lord Jesus Christ. ${ }^{94}$

While Anabaptists generally believed that property could be held privately it was never to be viewed as a wholly private matter but as a trust or stewardship from God which should always be held as available to one's brothers and sisters in Christ. To deny this is to deny the essential meaning of the Lord's Supper. For similar reasons profit making in commerce was condemned as a means of defrauding and exploiting the poor. The Hutterites (Stadler, Riedeman) advocated and practised a total renunciation of property. Here particularly the authorities could fear that revolution was on the horizon as a consequence of the Anabaptist vision. ${ }^{96}$

Yet this was not revolution, nor was it a series of unrelated responses to various passages of the New Testament, nor was it merely an attempt to be more radical than the magisterial reformers had been. The Hutterite commitment to community of goods was simply the most threatening aspect of an overall vision of the church as a 'gathered' brotherhood rather than an institution of a 'sacral society'; an ecclesiological outcome of a distinctive eschatological perception.

93 AO 190 f

94 Balthasar Hubmaier, 'A Chrisitian Instruction' (1526-7), quoted in AO 194.

$95 \mathrm{Cf} . \mathrm{AO} 232 \mathrm{f}$. 


\section{CONCLUSION}

One would hope, in conclusion, that the present pertinence of these issues pastorally would be obvious. In the context of a society which is becoming increasingly overtly secular the issue of the relatedness of the church to that society and the relatedness of both to the kingdom of God demands measured theological response. In 1964 George Beasley-Murray in a postscript to Verduin's The Reformers and their Stepchildren wrote:

A disturbing feature of the present situation is that in face of the universal increase of secularization, and the consequent growth of attitudes inimical to the Christian Faith and the Church, it is rarely admitted in official ecclesiastical quarters that it would be a good thing for the Church resolutely to abandon all ideas of the Church as coextensive with the State, and to acknowledge before all that the Constantinian ideal is dead. 96

If history appears to repeat itself it is only because the same ecclesiological issues raised by the early Anabaptists press themselves upon us whether or not we have the courage either to ask them or to attempt to frame answers. The manner in which eschatology determines ecclesiology is rarely recognized, even by those who to some degree would consider themselves to be the spiritual heirs of the early Anabaptists. The continuing emergence world-wide of 'new' churches and the remarkable growth of the so-called 'restoration' churches in this country can, in part, be understood as further responses to the same issues. The ecclesiological principles and practices of these new movements have a remarkably familiar ring. The following statement from 'some Swiss Brethren' in the sixteenth century could be contemporary:

When some one comes to church and constantly hears only one person speaking, and all the listeners are silent, neither speaking nor prophesying, who can or will regard or confess the same to be a spiritual congregation, or confess according to 1 Cor. 14 that God is dwelling and operating in them through his Holy Spirit with his gifts, impelling them one after the other in the above mentioned order of speaking and prophesying? ${ }^{97}$

96 G. R. Beasley-Murray, Postscript in Verduin, Stepchildren 280.

97 'Some Swiss Brethren' (1532-40) quoted in AO 127. 
But here again the implicit eschatological framework of these modern radical responses is rarely critically assessed: unfortunately one does not have to look too closely in some quarters to find the seeds of the eschatological presuppositions of Münster. However, if history may (in some instances) repeat itself in a catalogue of heterodoxy, schism and excess it is repeated also in the depressing reaction of dismissal, cynicism and caricature. I would suggest that now as then the latter is at least in part responsible for the former. The fertile seed-bed for the errors of excess and reaction is the ostrich-like attitude that stubbornly refuses to face awkward questions. The issues have been around for a long time. Their force is not diminished by them being ignored. Indeed, the present sociological and ecclesiastical context imposes such questions even more forcefully than before.

In John 17:11 Jesus prays to the Father on behalf of his disciples: 'protect them by the power of your name ... so that they may be one as we are one'. It is difficult to see how such divine protection could be operative without a willingness for dialogue, without an openness to face discomforting issues, without a commitment to theological integrity. 